\title{
Control of the bacteriological condition of calf brain. I. Impact of improving hygiene
}

\author{
Frans J.M. Smulders, Frank Korteknie and Caspar H.J. Woolthuis * \\ Department of the Science of Food of Animal Origin, Section Hygiene, Faculty of Veterinary Medicine. The \\ University of Utrecht, P.O. Box 80175, 3508 TD Utrecht, The Netherlands
}

(Received 29 February 1984, accepted 13 February 1985)

\begin{abstract}
Sixty calves of the Dutch Friesian $(\mathrm{FH})$ breed were stunned mechanically. Without previously having been stunned, another 30 calves were stuck according to the Jewish rite. Upon opening of the skulls $(1-2$ $\mathrm{h}$ post mortem) brains of mechanically stunned calves were collected either conventionally $(n=30)$ or "hygienically" $(n=30)$, i.e. using a fresh pair of surgical gloves during each removal to avoid cross contamination. For ritually slaughtered animals only the hygienic procedure was followed. Samples of 10 $\mathrm{g}$ were excised from undamaged hemispheres and in the mechanically stunned treatment group also from the site of impact of the captive bolt. After storage in polystyrene trays at $3 \pm 1^{\circ} \mathrm{C}$ for 7 days sampling was repeated. Bacteriological examination included the assessment of aerobic colony counts at $30^{\circ} \mathrm{C}$ for 3 days (ACC-30) and $4^{\circ} \mathrm{C}$ for 14 days (ACC-4) and Enterobacteriaceae colony counts at $37^{\circ} \mathrm{C}$ for $20 \mathrm{~h}$ (ECC). In conventionally collected samples the ACC-30 and ACC-4 were 3.8 and $3.0 \log _{10}$ cfu g $^{-1}$ at day 1 and 6.2 and $6.4 \log _{10} \mathrm{cfu}^{-1}$ at day 8 . With hygienic collection these counts were reduced by approximately $1 \log$ unit. Whilst by conventional practice the ECCs, at day 1 and 8 were 2.6 and $4.8 \log _{10}$ cfu $\mathrm{g}^{-1}$, these counts were 1.8 and $2.6 \log _{10} \mathrm{cfu}^{-1}$ for hygienic practice. In samples excised from the site of impact of the captive bolt the hygienic procedure had similar, though less marked effects. On day 1 brains from ritually slaughtered animals had a bacteriological contamination similar to that found in the hemispheres of mechanically stunned calves. However, whilst at day 8 their mean ECCs were 3.4 and 3.5 $\log _{10} \mathrm{cfu}^{-1}$ the percentages of plates 'positive' for Enterobacteriaceae were only $10 \%$ in the ritually vs. $53 \%$ in the mechanically stunned group. The Enterobacteriaceae in this case were composed of psychrotrophic non-pathogenic genera of environmental origin. Salmonella was not isolated from any sample.
\end{abstract}

Key words: Calf brain, bacteriology: Hygiene. improved

\section{Introduction}

The bacteriological condition of edible slaughter by-products and the manner in which this is affected by various handling procedures, packaging and storage conditions has been studied recently (Patterson and Gibbs, 1979; Bijker, 1981; Berry et al., 1981; Hanna et al., 1982a, b; Oblinger et al., 1982; Rothenberg et al., 1982; Smith et al., 1983; Woolthuis et al., 1984). The by-products studied included livers, tongues, udders, kidneys, skirts and tails.

\footnotetext{
* Present address: Food Inspection Service, Prinsegracht 50, 2512 GA The Hague. The Netherlands
} 
Another by-product, viz. calf brain, has received very little attention. though it is considered a delicacy in West European countries (Fisher, 1969). usually as a fried dish (Anon., 1981). It is also used as a basic component in sausages and in soups (von Ostertag and Schönberg, 1955; Linke, 1959). Calf brain contains approximately 9\% fat, $10 \%$ protein, including all essential amino acids, and it is relatively rich in $\mathrm{B}$ vitamins and vitamin C, compared to lean veal (Souci et al., 1969). It has been recommended as being particularly suitable for diabetes mellitus patients (Weitzel cited in von Ostertag and Schönberg, 1955).

Due to its particular tissue structure (i.e. a parenchymatous organ with very little mesenchymal interstitium) the conditions for bacterial colonization of brain are optimal. Its use in culture media for fastidious microorganisms substantiates this (Rosenow, 1919). Important factors determining the keeping quality of calf brain are (i) the extent of initial contamination as affected by manipulations and (ii) storage conditions from the moment of removal from the skull. The initial contamination is determined to a great extent by the stunning procedure. In essence three stunning methods are available for veal calves, viz. concussive, electrical, and captive bolt stunning. The latter method is generally used since it is considered the most practical one under the present conditions (Lambooy and Spanjaard, 1981). However, the captive bolt damages part of the brain, usually the cerebellum, forcing skin and bone fragments into the inner parts. Thus, brain tissue is inoculated with potentially hazardous microflora. Manual fixation of the head, splitting of the skull and removal of the brain imply other ways of contamination.

The purpose of the present study was to investigate whether paying particular attention to hygienic measures during the removal of the brain from the skull would significantly improve the bacteriological condition of brains originating from calves stunned by means of a captive bolt. Furthermore it seemed worthwhile investigating whether alternative stunning procedures not involving mechanical damaging of brain tissue might produce calf brain of superior bacteriological quality. To this end a series of experiments was conducted in which 'kosher' slaughtering (i.e. slaughtering according to the Jewish rite implying sticking without previous stunning) was used as a model for such alternatives.

\section{Materials and Methods}

\section{Samples}

A total of 60 calves of the Dutch Friesian $(\mathrm{FH})$ breed was stunned mechanically by means of a captive bolt. Without previously having been stunned another 30 calves were stuck according to the Jewish rite. Immediately after bleeding i.e. approximately $5 \mathrm{~min}$ post mortem carcasses were decapitated. Approximately at $1 \mathrm{~h}$ post mortem (for ritually slaughtered animals at $2 \mathrm{~h}$ ) the heads were skinned and hot boned and the skulls were opened. From heads of mechanically stunned animals the brain was removed either 'conventionally' ( 30 samples) or 'hygienically' ( 30 samples), whereas with ritually slaughtered calves only the latter procedure was followed. 
'Conventional' practice in the plant implied manual fixation of the head, splitting of the occipital bone by means of an axe and removal of the brain; all these manipulations were carried out by the same person without interim cleaning of the axe. 'Hygienic' practice relied on the same manipulations with exception of the removal of the brain from the skull, which was carried out by a second person wearing a fresh pair of surgical gloves during each removal in order to avoid cross contamination. Upon removal from the skull all brains were placed in polystyrene trays and stored for 7 days at $3 \pm 1^{\circ} \mathrm{C}$ in crates which were overwrapped with aluminium film to reduce the extent of desiccation. This procedure conforms to the storage conditions in practice.

\section{Bacteriological examination}

Samples for bacteriological examination were taken immediately after collection and in addition after 7 days of storage at $3 \pm 1{ }^{\circ} \mathrm{C}$. Using sterile surgical blades. cone-shaped samples with a base diameter of approximately $2 \mathrm{~cm}$ were excised from one of the hemispheres, and, in the case of brain originating from mechanically stunned animals, also from the site of impact of the captive bolt, usually the cerebellum. After maceration of $10 \mathrm{~g}$ brain tissue in a Stomacher (Gerats and Snijders, 1978) and resuscitation for $1 \frac{3}{4}-2 \mathrm{~h}$ at ambient temperatures in $90 \mathrm{ml}$ buffered peptone water (van Leusden et al., 1982) numbers of colony forming units (cfu) of the following microorganisms were assessed:

(1) Aerobic organisms; in poured plates of tryptone glucose beef extract agar (Difco 0002); incubation 3 days at $30^{\circ} \mathrm{C}$ and 14 days at $4^{\circ} \mathrm{C}$.

(2) Enterobacteriaceae; in poured plates of violet red bile glucose (VRBG) agar (Oxoid CM 485) with overlayer; incubation $20 \mathrm{~h}$ at $37^{\circ} \mathrm{C}$ (Mossel et al., 1962).

All samples resulting in plates appropriate for further examination [i.e. containing at least 7 typical Enterobacteriaceae colonies corresponding to $\log _{10} \mathrm{cfu} \mathrm{g}^{-1} \geqslant 1.8$ (Mossel and Drion, 1954)] were tested for Salmonella. For this purpose the remaining macerate was incubated at $37^{\circ} \mathrm{C}$ for $24 \mathrm{~h}$ after which $1.0 \mathrm{ml}$ was inoculated in 10 $\mathrm{ml}$ Muller-Kauffmann broth (Oxoid CM 343) and incubated at $43^{\circ} \mathrm{C}$ for another 24 $\mathrm{h}$. After plating on brilliant green agar (Oxoid CM 329) and incubation for $24 \mathrm{~h}$ at $37^{\circ} \mathrm{C}$. typical colonies were tested by assessing the type of growth in Kligler iron agar tubes (Difco 0086) and agglutination by polyvalent and subsequently group sera.

To study the composition of the Enterobacteriaceae flora of brain hygienically removed from ritually slaughtered calves, single colonies in VRBG were subcultured on MacConkey agar no. 3 (Oxoid CM 115) at $37^{\circ} \mathrm{C}$ and identified to genus level. The following criteria were used for that purpose: Gram stain, oxidase reaction, behaviour in a three-layer tube (allowing determination of mode of attack on glucose, motility and formation of indole and $\mathrm{H}_{2} \mathrm{~S}$ ), assimilation of citrate, dissimilation of urea and DNAase and gelatin activity. When required additional testing for $\beta$-galactosidase and attack on arabinose was done (Mossel et al., 1979). 
Statistical analysis of data.

For both aerobic colony counts and Enterobacteriaceae counts, plates were considered appropriate for enumeration when at least 7 colonies were present, corresponding to $\log _{10} \mathrm{cfu}^{-1} \geqslant 1.8$. All plates appropriate for enumeration of Enterobacteriaceae were also tested for Salmonella.

To determine the significance of differences between counts, the means of the four treatment combinations were compared pairwise with Fisher's LSD method, i.e. the $t$-test was used with a pooled variance estimate. For this purpose samples with less than 7 colonies in plates inoculated with the first decimal dilution $\left(\log _{10} \mathrm{cfu}\right.$ $\mathrm{g}^{-1}<1.8$ ) were assigned counts of $1.8 \mathrm{log}$ units.

\section{Results and Discussion}

Table I presents the aerobic colony counts at $30^{\circ} \mathrm{C}$ and at $4^{\circ} \mathrm{C}$, as well as colony counts of Enterobacteriaceae, expressed as $\log _{10} \mathrm{cfu}^{-1}$ brain tissue excised from the hemispheres of mechanically stunned animals.

As a result of hygienic practices at day 1 the percentage of plates appropriate for enumeration was drastically reduced in all counts. In the case of Enterobacteriaceae this occurred to such an extent that these bacteria remained 'undetectable'. The initial total colony counts at $30^{\circ} \mathrm{C}$ and at $4^{\circ} \mathrm{C}$ were approximately 1.5 and $1.0 \log _{10}$ units lower than with conventional practices $(p<0.001)$.

After 7 days of storage all samples of the conventionally collected brains yielded plates appropriate for enumeration on all media. Hygienically collected samples, however, still showed $47 \%$ of the samples being 'negative' for Enterobacteriaceae. Salmonellae were not detected in any sample examined. This substantiates earlier studies on the bacteriological condition of veal in the same plant (Smulders and

\section{TABLE I}

The bacteriological condition of undamaged hemispheres of calf brain after conventional $(n=30)$ and hygienic $(n=30)$ collection, measured initially (day 1$)$ and after 7 days of storage at $3 \pm 1^{\circ} \mathrm{C}$ (day 8); plates appropriate for enumeration (\%), mean bacterial colony counts and standard deviations $\left(\log _{10} \mathrm{cfu} \mathrm{g}^{-1}\right)$

\begin{tabular}{|c|c|c|c|c|}
\hline & \multicolumn{2}{|l|}{ Day 1} & \multicolumn{2}{|l|}{ Day 8} \\
\hline & Conventional & Hygienic & Conventional & Hygienic \\
\hline $\begin{array}{l}\text { Aerobic colony count } \\
\left(3 \text { days, } 30^{\circ} \mathrm{C}\right)\end{array}$ & $100 \% 3.8 \pm 0.6^{b *}$ & $60 \% \quad 2.3 \pm 0.3^{a}$ & $100 \% 6.2 \pm 0.7^{\mathrm{d}}$ & $100 \% 5.1 \pm 0.7^{c}$ \\
\hline $\begin{array}{l}\text { Aerobic colony count } \\
\left(14 \text { days, } 4^{\circ} \mathrm{C}\right)\end{array}$ & $97 \% 3.0 \pm 0.5^{b}$ & $20 \% 2.1 \pm 0.1^{\mathrm{a}}$ & $100 \% \quad 6.4 \pm 0.8^{d}$ & $100 \% 5.2 \pm 0.6^{\circ}$ \\
\hline $\begin{array}{l}\text { Enterobacteriaceae colony count } \\
\left(20 \mathrm{~h}, 37^{\circ} \mathrm{C}\right)\end{array}$ & $30 \% 2.6 \pm 0.4^{b}$ & $0 \%<1.8^{\mathrm{a}}$ & $100 \% 4.8 \pm 0.6^{c}$ & $\begin{array}{lll}53 \% & 3.4 \pm 0.8^{\circ}\end{array}$ \\
\hline
\end{tabular}

* In horizontal rows figures with different superscripts differ significantly $(p<0.05)$. 
Woolthuis, 1983), and is indicative of a relatively high standard of basic plant hygiene (Hobbs, 1964).

Table II presents aerobic colony counts at 30 and $4{ }^{\circ} \mathrm{C}$ as well as counts of Enterobacteriaceae expressed a $\log _{10} \mathrm{cfu}^{-1}$ brain tissue excised from the site of impact of the captive bolt. These results show that with respect to damaged brain areas, hygiene results in a less marked reduction of the percentage of plates appropriate for enumeration as compared with intact hemispheres: on day 1 only aerobic colony counts at $4^{\circ} \mathrm{C}$ and Enterobacteriaceae counts showed smaller percentages than controls did. However, all mean bacterial counts on day 1 were more than $1 \log _{10}$ unit lower. At day 8 only Enterobacteriaceae counts showed a slightly reduced percentage of countable plates $(p<0.05)$ whilst mean values for total colony counts at 30 and $4^{\circ} \mathrm{C}$ and Enterobacteriaceae are reduced by $0.4,0.5$ and 0.8 $\log _{10}$ units respectively $(p<0.025$ ). All samples positive for Enterobacteriaceae were examined for Salmonellae, but none were found to be positive. These results show that, in spite of the inevitable contamination of the brain with skin fragments in the course of the stunning process, hygienic practices may yet improve the bacteriological condition significantly.

Table III presents data on the bacteriological condition of brain originating from ritually slaughtered calves expressed as $\log _{10} \mathrm{cfu}^{-1}$. On day 1 the percentage of plates appropriate for enumeration was lower than with mechanical stunning, this being particularly evident when comparing the data with those on the damaged tissue (Table II, row 'hygienic'). All mean bacterial counts on day 1 were extremely low. For aerobic colony counts they hardly exceeded, and for Enterobacteriaceae counts were even less than their respective limits of detection, i.e. $\log _{10}=1.8$. Nonetheless, these figures were not significantly lower than those applying to hemisphere samples obtained by the hygienic procedure. This finding clearly illustrates that hygienic practices will suffice to prevent dispersion of bacteria from contaminated areas such as the site of impact of the captive bolt.

\section{TABLE II}

The bacteriological condition of calf brain at the site of impact of the captive bolt after conventional $(n=30)$ and hygienic $(n=30)$ collection, measured initially (day 1$)$ and after 7 days of storage at $3 \pm 1^{\circ} \mathrm{C}$ (day 8); plates appropriate for enumeration (\$), mean bacterial colony counts and standard deviation $\left(\log _{10} \mathrm{cfu} \mathrm{g}^{-1}\right)$

\begin{tabular}{|c|c|c|c|c|}
\hline & \multicolumn{2}{|l|}{ Day 1} & \multicolumn{2}{|l|}{ Day 8} \\
\hline & Conventional & Hygienic & Conventional & Hygienic \\
\hline $\begin{array}{l}\text { Aerobic colony count } \\
\left(3 \text { days, } 30^{\circ} \mathrm{C}\right)\end{array}$ & $100 \% \quad 5.0 \pm 0.9^{b}$ & $100 \% 3.8 \pm 0.8^{a}$ & $100 \% 6.9 \pm 0.7^{c}$ & $100 \% \quad 6.5 \pm 0.8^{c}$ \\
\hline $\begin{array}{l}\text { Aerobic colony count } \\
\left(14 \text { days, } 4^{\circ} \mathrm{C}\right)\end{array}$ & $100 \% 3.8 \pm 0.7^{b}$ & $63 \% 2.6 \pm 0.5^{a}$ & $100 \% 7.0 \pm 0.7^{d}$ & $100 \% 6.5 \pm 0.8^{c}$ \\
\hline $\begin{array}{l}\text { Enterobacteriaceae colony count } \\
\left(20 \mathrm{~h}, 17^{\circ} \mathrm{C}\right)\end{array}$ & $87 \% 3.5 \pm 1.2^{b}$ & $20 \% 2.5 \pm 0.4^{a}$ & $100 \% \quad 5.1 \pm 0.8^{c}$ & $93 \% \quad 4.3 \pm 0.8^{c}$ \\
\hline
\end{tabular}

* In horizontal rows figures with different superscripts differ significantly $(p<0.05)$. 


\section{TABLE III}

The bacteriological condition of brain hygienically removed from ritually slaughtered calves $(n=30)$. measured initially (day 1 ) and after 7 days of storage at $3 \pm 1^{\circ} \mathrm{C}$ (day 8): plates appropriate for enumeration $(\%)$. mean bacterial counts and standard deviation $\left(\log _{10} \mathrm{cfu} \mathrm{g}^{-1}\right)$

\begin{tabular}{lllll}
\hline & Day 1 & \multicolumn{3}{c}{ Day 8} \\
\hline Aerobic colony count $\left(3\right.$ days, $\left.30^{\circ} \mathrm{C}\right)$ & $43 \%$ & $2.3 \pm 0.3^{\mathrm{a} * *}$ & $100 \%$ & $5.6 \pm 0.9^{\mathrm{b}}$ \\
Aerobic colony mount $\left(14\right.$ days. $\left.4^{\circ} \mathrm{C}\right)$ & $7 \%$ & $2.1 \pm 0.1^{\mathrm{c}}$ & $100 \%$ & $6.1 \pm 0.9^{\mathrm{b}}$ \\
Enterobacteriaceae colony count $\left(20 \mathrm{~h}, 37^{\circ} \mathrm{C}\right)$ & $0 \%$ & $<1.8^{\mathrm{a}}$ & $10 \%$ & $3.5 \pm 1.1^{\mathrm{b}}$ \\
\hline
\end{tabular}

* In horizontal rows figures with different superscripts differ significantly $(p<0.001)$.

In view of the similar initial contamination of hemispheres of ritually slaughtered and mechanically stunned animals one would expect to find negligible differences in contamination levels on day 8 . Nevertheless Table III shows aerobic colony counts at 30 and $4^{\circ} \mathrm{C}$ to have increased to levels even higher than those observed in samples obtained by mechanical stunning ( $p<0.01$ and $p<0.001$, respectively), probably due to differences in composition of the initial contaminating microflora. Moreover, after one week of chilled storage, $10 \%$ of the plates became positive for Enterobacteriaceae which corresponded to a mean count of $3.5 \log _{10}$ units. Although the counts were significantly lower compared to counts of the mechanically stunned group, recontamination with Enterobacteriaceae was not expected in view of the hygienic measures taken during removal of the brain.

These results prompted a survey on the composition of the Enterobacteriaceae flora from brains of kosher-slaughtered calves after one week of storage at $3 \pm 1^{\circ} \mathrm{C}$. For this purpose all colonies obtained in VRBG plates were streaked onto plates with MacConkey agar incubated at $37^{\circ} \mathrm{C}$ and single colonies thus obtained examined for the traits of the main genera of Enterobacteriaceae by the procedures described earlier. In addition to assessing their psychrotrophic character, cultures from these colonies were made in brain heart infusion broth (BHI) (Oxoid CM 225) incubated at $37^{\circ} \mathrm{C}$ and subcultured on VRBG plates incubated at 30 as against $43^{\circ} \mathrm{C}$ (Mossel and Zwart. 1960).

$83 \%$ of the colonies were confirmed to be Enterobacteriaceae. Table IV presents

\section{TABLE IV}

Distribution of genera $(\mathscr{D})$ within the Enterobacteriaceae family isolated from calf brain, hygienically removed from ritually slaughtered calves $(n=30)$

\begin{tabular}{lr}
\hline Hafnia & 56 \\
Serratia & 24 \\
Erwinia & 16 \\
'Alkalescens-Dispar * & 4 \\
\hline
\end{tabular}

- Anaerogenic, non-motile variant of Escherichia coli. 
the distribution of genera within these Enterobacteriaceae. All Enterobacteriaceae colonies were found to grow on VRBG agar at $30^{\circ} \mathrm{C}$, but not at $43^{\circ} \mathrm{C}$. With the exception of the Alkalescens-Dispar isolate they showed negative response in lactose dissimilation tests $\left(24 \mathrm{~h} / 30^{\circ} \mathrm{C}\right)$ and would consequently have been missed in conventional coli-aerogenes determinations.

The Enterobacteriaceae flora did not comprise genera of specific animal origin. This indicates that in the present experiment dispersion of bacteria via blood or faeces during or after removal of the brain from the skull had been successfully avoided. The finding that only VRBG surface plates incubated at $30^{\circ} \mathrm{C}$ showed any growth is in agreement with data of van der Zee et al. (personal communication) indicating that non-pathogenic Enterobacteriaceae will generally not grow at $43^{\circ} \mathrm{C}$. Consequently the slight increase in the Enterobacteriaceae load in the present experiment is the result of contamination with environmental types of a psychrotrophic nature that are known to be harmless for man, with the exception of Yersinia species (Mossel, 1982).

Our findings illustrate once more the need to segregate enteric contamination of foods of animal origin from subsequent proliferation of bacteria of environmental origin (Mossel, 1982). These data also substantiate that brain tissue is extremely susceptible to bacterial spoilage under the conditions of chilled storage conventionally applied.

\section{Acknowledgements}

The authors gratefully acknowledge the support of the Veterinary Service of Public Health at The Hague and EKRO b.v. at Apeldoorn for supporting this study. Thanks are also due to the municipal slaughterhouse at 's-Hertogenbosch for assisting in the experimentation.

\section{References}

Anonymous, 1981. The good cook - offals. Time-Life Books Inc., Amsterdam, pp. 104-106.

Berry, B.W. C.A. Rothenberg, J.L. Oblinger, W.R. Miller, A.J. Bongers and H. Labots, 1981. Microbial shelfife characteristics of beef variety meats under actual and simulated export conditions. Proc. 27th Eur. Meet. Meat Res. Work., Vienna. II, 691-694.

Bijker. P.G.H., 1981. Hygienic aspects of edible offals, Ph.D. Thesis, Faculty of Veterinary Medicine. The University of Utrecht. 147 pp.

Fisher, M.F.K.. 1969. The cooking of provincial France. Time-Life Books Inc., Amsterdam, pp. $132-133$.

Gerats, G.E. und J.M.A. Snijders, 1978. Bestimmung von Keimzahlen in der Fleischindustrie, das Stomacherverfahren und das Spiralplattenverfahren. Arch. Lebensm. Hyg. 29, 57-61.

Hanna, M.O., G.C. Smith. J.W. Savell, F.K. McKeith and G. Vanderzant, 1982a. Microbial flora of livers, kidneys and hearts from beef, pork and lamb: effects of refrigeration, freezing and thawing. J. Food Prot. 45, 63-73.

Hanna. M.O.. G.C. Smith, J.W. Savell, F.K. McKeith and C. Vanderzant. 1982b. Effects of packaging methods on the microbial flora of livers and kidneys from beef and pork. J. Food Protect. 45, 74-81. 
Hobbs, B.C., 1964. Salmonella in foods. Proc. National Conf. on Salmonellosis, 11-13th March. U.S. Department of Health, Education and Welfare, Public Health Service, Washington D.C.. pp. 84-93.

Lambooy, E. and W. Spanjaard, 1981. Effect of the shooting position on the stunning of calves by captive bolt. Vet. Rec. 109, 359-361.

Linke, H., 1959. Histologischer Nachweis von Gehirn in Brühwürsten. Fleischwirtschaft 39, 999-1001.

Mossel.' D.A.A. and E.F. Drion, 1954. Bacteriological requirements for and testing of sterilized milk and sterilized milk products. Netherl. Milk Dairy J. 8, 106-114.

Mossel, D.A.A. and H. Zwart, 1960. The rapid tentative recognition of psychrotrophic types among Enterobacteriaceae isolates from foods. J. Appl. Bact. 23, 185 188 .

Mossel, D.A.A., W.H.J. Mengerink and H.M. Scholts, 1962. Use of a modified MacConkey agar medium for the selective growth and enumeration of Enterobacteriaceae. J. Bacteriol. 84, 381 .

Mossel. D.A.A.. I. Eelderink, M. Koopmans and F. van Rossum, 1979. Influence of carbon source, bile salts and incubation temperatures on recovery of Enterobacteriaceae from foods using MacConkey-type agars. J. Food Protect. 42, 470-475.

Mossel. D.A.A., 1982. Microbiology of Foods, the ecological essentials of assurance and assessment of safety and quality, 3rd ed.. The University of Utrecht. Faculty of Veterinary Medicine. The Netherlands, $181 \mathrm{pp}$.

Oblinger. J.L.. J.E. Kennedy Jr.. C.A. Rothenberg. B.W. Berry and N.J. Stern. 1982. Identification of bacteria isolated from fresh and temperature abused variety meats. J. Food Protect. 45. 650-654.

Patterson, J.T. and P.A. Gibbs, 1979. Vacuum packaging of bovine edible offal. Meat Sci. 3, 209-222.

Rosenow, E.C., 1919. Studies on elective localizations-focal infection with special reference to oral sepsis. J. Dental Res. 1, 205-264.

Rothenberg. C.A.. B.W. Berry and J.L. Oblinger, 1982. Microbial characteristics of beef tongues and livers as affected by temperature-abuse and packaging systems. J. Food Prot. 45, 527-536.

Smith, G.C.. B.W. Berry, J.H. Lennon and J.W. Savell, 1983. Transoceanic shipment of chilled variety meats. J. Food Protect. 46. 728-730.

Smulders, F.J.M. and C.H.J. Woolthuis, 1983. Influence of two levels of hygiene on the microbiological condition of veal as a product of two slaughtering/processing sequences. J. Food Protect. 46. $1032-1035$

Souci, S.W., W. Fachmann und H. Kraut, 1969. Die Zusammensetzung der Lebensmittel, Nährwert Tabellen. Wissenschaftliche Verlagsgesellschaft M.B.H., Stuttgart, p F-II, 16.

van Leusden, F.M., M. van Schothorst and H.J. Beckers, 1982. The standard Salmonella isolation method. In: Isolation and identification methods for food poisoning organisms, edited by J.E.L. Corry. D. Roberts and F.A. Skinner. Academic Press, London, pp 35-49.

von Ostertag. R. und F. Schönberg. 1955. Lehrbuch der Schlachttier- und Fleischuntersuchung. Ferdinand Enke Verlag. Stuttgart, p. 231.

Woolthuis, C.H.J., D.A.A. Mossel, J.G. van Logtestijn, J.M. de Kruyff and F.J.M. Smulders. 1984. Microbial decontamination of porcine liver with lactic acid and hot water. J. Fond Protect. 47. $220-226$. 